\title{
Glosa do wyroku Sądu Apelacyjnego w Rzeszowie z dnia 15 lipca 2015 r. III AUa 264/15
}

1.

Teza, która wynika z glosowanego orzeczenia, brzmi następująco: „racjonalny w swych działaniach ustawodawca przewidział i dopuścił możliwość deklarowania przez prowadzących pozarolniczą działalność gospodarczą (jak też osób z nimi współpracujących) podstawy wymiaru składek oderwanej w swej wysokości od faktycznego przychodu”.

\section{2.}

Problem prawny, którym zajął się Sąd Apelacyjny w Rzeszowie, sprowadza się do wykładni art. 18 ust. 8 ustawy z dnia 13 października 1998 r. o systemie ubezpieczeń społecznych ${ }^{2}$, zgodnie z którym podstawę wymia-

\footnotetext{
LEX nr 1768711.

2 Tekst jedn. Dz.U. z 2015 r., poz. 121 ze zm.
} 
ru składek na ubezpieczenia emerytalne i rentowe ubezpieczonych, o których mowa w art. 6 ust. 1 pkt 5 (tj. osób prowadzących pozarolniczą działalność oraz osób z nimi współpracujących), stanowi zadeklarowana kwota, nie niższa jednak niż $60 \%$ prognozowanego przeciętnego wynagrodzenia miesięcznego przyjętego do ustalenia kwoty ograniczenia rocznej podstawy wymiaru składek, ogłoszonego w trybie art. 19 ust. 10 na dany rok kalendarzowy.

Decyzją z dnia 30 maja 2014 r. ZUS ustalił podstawę wymiaru składek na ubezpieczenie społeczne M.G. z tytułu współpracy w kwocie odpowiadającej $60 \%$ prognozowanego przeciętnego miesięcznego wynagrodzenia, nie akceptując tym samym deklarowanej przez ubezpieczoną od 1 listopada 2013 r. podstawy wymiaru składek w wysokości ponad 9 tys. zł. Należy wskazać, że M.G. zaczęła korzystać z zasiłku chorobowego od 14 lutego 2014 r. ZUS uznał, że wprawdzie zgłoszenie M.G. do ubezpieczeń społecznych jako osoby współpracującej było zasadne, to jednak zadeklarowanie maksymalnej stawki podstawy wymiaru składek „należy ocenić jako naruszające zasady współżycia społecznego, co ostatecznie prowadzi do przyjętej korekty tej podstawy.”

\section{3.}

Glosowany wyrok zasługuje na uwagę przede wszystkim ze względu na ostatnie zdanie uzasadnienia: „Na koniec nasuwa się zaś generalna uwaga, że o ile działania racjonalnego ustawodawcy zmierzają do stworzenia swoistej zachęty dla prowadzących działalność gospodarczą do deklarowania przez nich kwot wyższych od minimalnych, celem istotnego zasilania Funduszu, okazały się ostatecznie płonne, stając się zarazem polem do różnego rodzaju nadużyć, to nie pozostaje nic innego jak tylko zmiana obowiązujących w tym względzie przepisów prawa, co z oczywistych względów nie leży w gestii orzekających sądów (wiadomym jest przy tym, że jeszcze w 2012 r. Ministerstwo Pracy i Polityki Społecznej zaproponowało rządowi zmianę przepisu ustawy zasiłkowej dotyczącego zasad wyliczania zasiłku macierzyńskiego - zmiana dotyczyć miała osób, które opłacałyby składkę chorobową krócej niż 12 miesięcy od wyższej pod- 
stawy niż najniższa, gdzie ta ostatnia właśnie miała stać się punktem wyjścia do wyliczania zasiłku macierzyńskiego), ale na razie działania te okazały się bezskuteczne”. Sąd Apelacyjny w Rzeszowie trafnie więc i dobitnie stwierdził, że jego rolą nie jest poprawianie błędów ustawodawcy, który chciał zrealizować pewne cele, ale mu się to w praktyce nie udało. Sąd, dokonując wykładni przepisów, przyjmuje, że ustawodawca jest racjonalny.

\section{4.}

W stosunku do osób prowadzących pozarolniczą działalność gospodarczą oraz osób z nimi współpracujących, ustawodawca zrezygnował z przyjęcia „naturalnej” podstawy wymiaru składek ${ }^{3}$. W literaturze wskazuje się trafnie, że „Zasada, że podstawę wymiaru składki stanowi faktyczny przychód ubezpieczonego, nie zawsze jednak może być zastosowana. Zdarza się, że przychód nie jest możliwy do udokumentowania albo ubezpieczony nie ma go w ogóle. W takich sytuacjach ustawodawca pozwala, aby ubezpieczony sam oznaczył (zadeklarował), jaki przychód osiąga albo od jakiego chce płacić składkę." ${ }^{4}$ Ustawodawca nakreślił jednak pewne ramy, w zakresie których ubezpieczony może deklarować podstawę wymiaru składek. Minimalna podstawa wymiaru składek dla osób prowadzących pozarolniczą działalność gospodarczą oraz osób z nimi współpracujących to kwota nie niższa niż 60\% prognozowanego przeciętnego wynagrodzenia miesięcznego przyjętego do ustalenia kwoty ograniczenia rocznej podstawy wymiaru składek, ogłoszonego w trybie art. 19 ust. 10 na dany rok kalendarzowy. Z kolei maksymalny wymiar określony jest przez art. 19 ust. 1 ustawy systemowej (dla ubezpieczenia emerytalnego i rentowych). Z art. 20 ust. 2 ww. ustawy wynika, że w zakresie podstawy wymiaru składek na ubezpieczenie chorobowe i wypadkowe ograniczenie, wynikając z art. 19 ust. 1, nie ma zastosowania, jednak art. 20 ust. 3

3 Obszernie nt. podstawy wymiaru składek zob. np. J. Wantoch-Rekowski, Składki na ubezpieczenie emerytalne. Konstrukcja i charakter prawny, Toruń 2005, s. 153-162 i cyt. tam literatura.

4 I. Jędrasik-Jankowska, Ubezpieczenie emerytalne. Trzy filary, Warszawa 2001, s. 81. 
wskazuje, że podstawa wymiaru składek na ubezpieczenie chorobowe osób, które ubezpieczeniu chorobowemu podlegają dobrowolnie, nie może przekraczać miesięcznie 250\% prognozowanego przeciętnego wynagrodzenia, o którym mowa w art. 19 ust. 10. Zatem - oprócz składek na ubezpieczenie wypadkowe - ustawodawca ograniczył swobodę deklarowania wysokich podstaw wymiaru składek poprzez ustalenie wartości maksymalnych (w skali roku lub miesiąca).

Z żadnego przepisu ustawy o systemie ubezpieczeń społecznych nie wynika, aby kwota deklarowana przez ubezpieczonego była uzależniona od czegokolwiek, z wyjątkiem woli samego ubezpieczonego. W szczególności brak powiązania dochodów ubezpieczonego, czy też jego sytuacji majątkowej, z deklarowaną podstawą wymiaru składek.

\section{5.}

Wraz z pogarszającą się sytuacją finansową Funduszu Ubezpieczeń Społecznych intensyfikują się profiskalne działania ZUS, mające ma celu maksymalizowanie przychodów i ograniczanie wydatków z Funduszu Ubezpieczeń Społecznych. ZUS najczęściej „reaguje” w sytuacji, gdy zachodzi konieczność wypłaty stosunkowo wysokich świadczeń. Nie sposób oprzeć się wrażeniu, że w części decyzji wydawanych przez ZUS zastosowanie ma wykładnia contra legem przepisów ubezpieczeniowych, jednakże interes ubezpieczonych (płatników składek) jest chroniony przez sądy, które rozpatrują odwołania od tych decyzji.

Jest oczywiste, że wśród licznych orzeczeń można spotkać i takie, z którymi nie sposób się zgodzić. Bywają one wykorzystywane przez ZUS dla uzasadnienia przyjętej wykładni. Przykładowo można wskazać, że glosowany wyrok oddalił apelację organu rentowego od wyroku sądu I instancji, w której to ZUS podnosił, że zadeklarowanie podstawy wymiaru składek w oderwaniu do sytuacji finansowej prowadzącego pozarolniczą działalność gospodarczą i osoby z nim współpracującej narusza art. 5 Kodeksu cywilnego. Jako potwierdzenie swojego stanowiska ZUS 
wskazał wyrok Sądu Okręgowego w Białymstoku z dnia 30 grudnia 2013 r. ${ }^{5}$ W orzeczeniu tym sąd m.in. stwierdził: „Jednak nie do przyjęcia jest sytuacja, w której przedsiębiorca przez kilka lat płaci najniższą składkę, a osoba współpracująca z nim przez miesiąc lub dwa najwyższą. Solidaryzm społeczny nie polega na zapewnieniu zysku, którego nawet na giełdzie w okresie hossy nie można byłoby uzyskać. Kierując się takimi motywami, Sąd uznał, że podstawa wymiaru składek E.K. powinna być taka jak jej męża.” Sąd Okręgowy nie wziął pod uwagę, że stosowanie przepisów Kodeksu cywilnego do regulacji dotyczących składek na ubezpieczenia społeczne ma bardzo ograniczony zakres. Sąd Najwyższy w wyroku z dnia 5 grudnia 2007 r. ${ }^{6}$ stwierdził, że „prawo ubezpieczeń społecznych stanowi odrębną gałąź prawa w stosunku do prawa cywilnego, a jego przepisy mają charakter przepisów prawa publicznego, w których strony nie korzystają ze swoich praw podmiotowych regulowanych prawem prywatnym - Kodeksem cywilnym lub Kodeksem pracy, lecz w których Zakład Ubezpieczeń Społecznych realizuje wobec innego uczestnika stosunku prawnego ustawowe kompetencje organu władzy publicznej. Z tego względu stosunek ubezpieczenia społecznego nie jest stosunkiem cywilnoprawym, opartym na równorzędności jego podmiotów i wzajemności (ekwiwalentności) świadczeń, lecz uregulowanym ustawowo stosunkiem publicznoprawnym opartym na zasadzie solidaryzmu, a wynikające z niego świadczenia stron tego stosunku nie są świadczeniami cywilnoprawnymi."

W innym, istotnym dla tego zagadnieniu orzeczeniu - w uchwale Sądu Najwyższego (skład 7 sędziów) z dnia 21 kwietnia 2010 r. ${ }^{7}$ - stwierdzono: „Autonomiczność i odrębność przepisów prawa ubezpieczeń społecznych wobec przepisów prawa cywilnego sprawia, iż na gruncie stosunków ubezpieczenia społecznego dopuszcza się tylko na zasadzie wyjątku stosowanie wskazanych expressis verbis regulacji cywilistycznych”. Sąd Najwyższy wskazał także, że „do stosunku ubezpieczenia społecznego nie stosuje się przepisów prawa cywilnego, wobec czego kwestiono-

\footnotetext{
V U 1874/13, Portal Orzeczeń Sądu Okręgowego w Białymstoku (dostęp: 15.12.2015 r.). II UK 106/07, LEX nr 346189.

II UZP 1/10, LEX nr 575822.
} 
wanie przez Zakład Ubezpieczeń Społecznych zadeklarowanej w granicach przewidzianych ustawą przez osobą prowadzącą pozarolniczą działalność podstawy wymiaru składek z powołaniem się na art. 58 k.c., czy art. 5 k.c. nie jest możliwe.”

Zwraca się na to także uwagę w literaturze - wg J. Jończyka stosunki zabezpieczenia społecznego wynikają z ustawowego uprawnienia i obowiązku. Autor wskazuje, że „Nie ma tu miejsca na autonomię stron, na dobrowolność (poza wyjątkami, które są jednak coraz liczniejsze), na umowne kształtowanie treści stosunków zabezpieczenia społecznego, w takim choćby zakresie, jaki znany jest w prawie pracy.",

\section{6.}

Podkreślić należy, że deklarowanie przez prowadzących pozarolniczą działalność i osoby z nimi współpracujące podstawy składek oderwanej w swej wysokości od faktycznego przychodu zgodne jest z treścią art. 18 ust. 8 ustawy systemowej. Przeciwdziałanie zjawisku „zarabiania” na świadczeniach poprzez deklarowanie wysokiej podstawy wymiaru składek na ubezpieczenia społeczne w okresie bezpośrednio poprzedzającym korzystanie ze świadczeń, nie może odbywać się poprzez wydawanie przez ZUS decyzji opartych na nieprawidłowej wykładni przepisów ubezpieczeniowych. Realną możliwością jest znowelizowanie odpowiednich przepisów dotyczących świadczeń ubezpieczeniowych, aby krótkotrwałe podwyższanie podstawy wymiaru składek do wartości maksymalnych nie było opłacalne dla ubezpieczonych.

Wszelkie próby kwestionowania przez ZUS podstawy wymiaru składek w stosunku do osób prowadzących pozarolniczą działalność i osób z nimi współpracujących w wysokości deklarowanej, jednak mieszczącej się w ustawowych ramach, uznać należy za błędne.

8 J. Jończyk, Prawo zabezpieczenia społecznego, Kraków 2001, s. 11. 


\section{Bibliografia:}

Jędrasik-Jankowska I., Ubezpieczenie emerytalne. Trzy filary, Wydawnictwa Prawnicze PWN, Warszawa 2001.

Jończyk J., Prawo zabezpieczenia społecznego, Kantor Wydawniczy Zakamycze, Kraków 2001.

Wantoch-Rekowski J., Składki na ubezpieczenie emerytalne. Konstrukcja i charakter prawny, Towarzystwo Naukowe Organizacji i Kierownictwa „Dom Organizatora”, Toruń 2005. 